\title{
The Effect of Familial Mediterranean Fever Disease on The Cornea
}

\author{
(iD) Ahmet Elbeyli ${ }^{1}$ \\ ${ }^{1}$ Asst. Prof., Mustafa Kemal University Faculty of Medicine, Department of Ophthalmology, Hatay, Turkey.
}

$\ddot{0} z$

Ailevi Akdeniz Ateșinin Korneaya Etkisi

Amaç:Ailevi Akdeniz Ateși (AAA) hastalarında korneal yapısal değişiklikleri araștırmak.

Gereç ve Yöntem: Çalıșmaya AAA hastası olan 64 kiși (çalıșma grubu) ile herhangibir göz hastalığı olmayan, yaș ve cinsiyet uyumlu 49 kişi kontrol grubu olarak alındı. Santral kornea kalınlığı, endotel hücre sayısı (EHS), hücrelerin hegzagonalite yüzdesi(HEXA) ve varyasyon katsayısı (VK) ultrasonik pakimetre ile değerlendirildi.

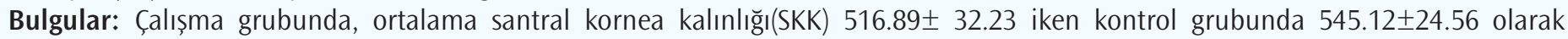
bulundu. Endotel hücre sayısı(EHS), hegzagonalite yüzdesi(HEXA) ve hücre varyasyon katsayısı(VK) sırasıyla $3402.51 \pm 383.84$ cells/mm², $26.72 \pm 4.55 \%$, and $68.60 \pm 8.63 \%$ idi. Kontrol grubunda ise aynı parametreler $3339.46 \pm 322.60$ cells $/ \mathrm{mm}^{2}, 27.59 \pm 5.23 \%$, ve $67.34 \pm 9.38 \%$ olarak bulundu. Bu parametrelerden santral kornea kalınlığı(CCT) ise iki grup arasında istatiksel olarak anlamlı farklı bulundu(p=0.011). Sonuç: Çalıșma sonuçlarına göre AAA hastalarında, sağlıklı bireyler ile karșılaștırıldı̆̆ında önemli korneal morfolojik-yapısal değișiklikler olabilir.

Anahtar Kelimeler: Ailevi Akdeniz Ateşi, Kornea, İnflamasyon, Santral Korneal Kalınlık, Korneal Endotel

\section{Abstract}

\section{The Effect of Familial Mediterranean Fever Disease on The Cornea}

Objective: To investigate corneal structural in patients with Familial Mediterranean Fever (FMF).

Methods: This case-control study included 64 patients with FMF and, 49 age and gender similar healthy subjects without any eye disease. Endothelial cell density (ECD), the coefficient of variation in cell size (CV) and percentage of hexagonality were measured by non-contact specular microscopy, central corneal thickness (CCT) was measured by ultrasonic pachymetry.

Results: The mean CCT value was 516.89 $\pm 32.23 \mu \mathrm{m}$ in the study group and $545.12 \pm 24.56 \mu \mathrm{m}$ in the control group. The mean ECD, CV, and percentage of hexagonality values were $3402.51 \pm 383.84$ cells $/ \mathrm{mm}^{2}, 26.72 \pm 4.55 \%$, and $68.60 \pm 8.63 \%$ in the study group, respectively and $3339.46 \pm 322.60$ cells $/ \mathrm{mm}^{2}, 27.59 \pm 5.23 \%$, and $67.34 \pm 9.38 \%$ in the control group, respectively. Of these parameters, the CCT values were statistically significantly different between the study and control groups $(p=0.011)$.

Conclusion: Compared to healthy individuals, patients with FMF may have significant morphological changes in the structure of the cornea.

Keywords: Familial Mediterranean Fever, Cornea, Inflammation, Central Corneal Thickness, Corneal Endothelium

Nasıl Atıf Yapmalı: Elbeyli A. The Effect of Familial Mediterranean Fever Disease on The Cornea. MKÜ Tıp Dergisi. 2021;12(44):226-230. https://doi.0rg/10.17944/ mkutfd. 978113 


\section{INTRODUCTION}

FMF is a disease with recurrent attacks of fever, arthritis and serositis. Recently, there has been frequent discussion of findings of vasculitis that are seen in FMF patients. FMF is widespread among populations of eastern Mediterranean origin such as non-Ashkenazy Jews, Arabs, Turks and Armenians (1).

When the genetic analysis is made of patients, it is seen to be consistent with an autosomal recessive pattern of inheritance. Previous studies which have determined some mutations have shown that these mutations originate from the Eastern Mediterranean and are based on a very long history. The gene responsible for the disease was identified in 1997, and FMF was defined as "impairment in the response to inflammation in the organisms a result of mutations in the MEFV gene" (2).

The MEFV gene encodes the pyrin protein and this immunoregulatory molecule consists of 781 amino acids and although the definitive physiological role is not clear it is assumed to play a part in the regulation of inflammation, apoptosis, and cytokine production $(3,4)$.

There is a wide spectrum of effects of inflammation on the eye and vision. In literature, it has been reported that the frequency of episcleritis, posterior scleritis and uveitis (anterior, intermediary and posterior) is increased in FMF patients. There are also studies that have reported retinal amyloidosis and conjunctival goblet cell destruction (5).

Since the cornea is the most important refractive element of the eye and other corneal diseases, accurate evaluation of the cornea has become very important in refractive surgery, which has been increasingly performed. Kosekahya et al. mentioned that FMF patients have an increased risk of corneal ectasia compared to healthy subjects (6). However, the effect of FMF on corneal morphology is still not clear. The studies related to the cornea in FMF patients are insufficient. Therefore, this study aimed to investigate whether FMF affects the corneal structure with the use of specular microscopy and pachymetry.

\section{MATERIALS AND METHODS}

This case-control study included 64 patients with FMF and 49 age and gender-matched healthy subjects without any eye disease apart from refractive errors and the data of all participants of the study were analyzed retrospectively. Among the subjects who applied to the tertiary care hospital for a routine examination. As the control group, 49 healthy, age and gender matched individuals were included in the study.

The majority of FMF patients were in the pediatric age group and were referred to us by the pediatric or genetics clinics. Patients diagnosed with FMF based on clinical and ge- netic analysis results were consulted to us for ocular inflammatory complications. Patients with FMF had used colchicine for an average of 3.1(2-8) years and had clinical symptoms for 4.3(3-10) years.

Potential subjects with any ocular surface disorder, glaucoma, intraocular surgery, uveitis, corneal dystrophy or degeneration, contact lens wear, or a history of diabetes, and subjects using topical ophthalmic and/or systemic drug(s) in both groups were also excluded from the study.

All subjects were examined by the same ophthalmologist. The examination included best corrected visual acuity, slit lamp biomicroscopy, intraocular pressure measurement, and fundoscopy, in addition to specular microscopy and pachymetry measurements. Central corneal thickness (CCT) measurements were obtained with a pachymeter (Nidek, Echoscan US- 4000, Japan). ECD, percentage of hexagonality, and CV were performed using non-contact specular microscopy (Topcon SP 3000P, Topcon Corp., Tokyo, Japan). Three digital photographs of the central cornea were taken to assess endothelial cells. Using these photographs, measurements of $E C D$, percent hexagonality, and coefficient of variation in cell size (CV) were obtained based on the study of McCarey et al. (7). According to the study of Doughty et al(8), photographs with endothelium of $\geq 75$ countable cells were included for reliability assessments.

The number of cells in $1 \mathrm{~mm} 2$ area was defined as ECD. The percentage of hexagonal cells is the percentage of 6-sided cells and is a measure of the degree of pleomorphism. The coefficient variation is the calculated degree of polymegathism and was obtained by dividing the standard deviation by the mean cell area. These values were calculated automatically by specular microscopy.

\section{Statistical Analysis}

Data analysis was conducted using SPSS version 16.0 (IBM Corporation, Chicago, IL, USA). Data were given as mean \pm standard deviation (SD) and median (min-max) values, and categorical data as number (n) and percentage (\%). The conformity of continuous variables to normal distribution was tested with the Kolmogorov-Smirnov test. The Chi-square test was used for comparisons between categorical variables. The Student's t-test was used to compare age, ECD, CCT, CV, and the percentage of hexagonality between the groups. A value of $p<0.05$ was considered statistically significant. Because of the FMF is an uncommon disease in the community, no power analysis was done.

\section{RESULTS}

The study comprised 22 males and 42 females with a mean age of $8.6 \pm 3.4$ years in the study group, and 24 males and 25 females with a mean age of $9.5 \pm 2.6$ years in the con- 
trol group. There was no significant difference between the groups in terms of age or gender. The mean CCT value was $516.89 \pm 32.23 \mu \mathrm{m}$ in the study group and $545.12 \pm 24.56 \mu \mathrm{m}$ in the control group. The CCT values were significantly lower in the study group than the control group $(p=0.011)$. The mean ECD, CV, and percentage of hexagonality values in the study group were $3402.51 \pm 383.84$ cells $/ \mathrm{mm}^{2}, 26.72 \pm 4.55 \%$, and $68.60 \pm 8.63 \%$, respectively, and $3339.46 \pm 322.60$ cells/ $\mathrm{mm}^{2}, 27.59 \pm 5.23 \%$, and $67.34 \pm 9.38 \%$ in the control group, respectively (Table 1 ).

Table 1. The mean corneal parameter values, and demographic data in the study and control groups

\begin{tabular}{|l|c|c|c|} 
& $\begin{array}{c}\text { FMF group }(\mathrm{n}=64) \\
\text { mean } \pm \text { SD }\end{array}$ & $\begin{array}{c}\text { Control group }(\mathrm{n}=49) \\
\text { mean } \pm \text { SD }\end{array}$ & p values \\
\hline Age, (years) & $8.6 \pm 3.4$ & $9.5 \pm 2.6$ & 0.130 \\
\hline Gender, (M/F) & $22 / 42$ & $24 / 25$ & 0.127 \\
\hline CV, (\%) & $26.72 \pm 4.55$ & $27.59 \pm 5.23$ & 0.346 \\
\hline ECD, (cells/mm²) & $3402 \pm 383$ & $3339 \pm 322$ & 0.356 \\
\hline HEXA, $(\%)$ & $68.60 \pm 8.63$ & $67.34 \pm 9.38$ & 0.460 \\
\hline CCT, $(\boldsymbol{\mu m})$ & $516.89 \pm 32.23$ & $545.12 \pm 24.56$ & $<0.001$ \\
\hline
\end{tabular}

$\mathbf{E C D}=$ endothelial cell density, $\mathbf{C V}=$ coefficient of variation in cell size, $\mathbf{H E X A}=$ percentage of hexagonality, $\mathbf{C C T}=$ central corneal thickness. $\mathbf{F}=$ female, $\mathbf{M}=$ male.

Chi-square tests and Student's $t$ tests were used. Bold $p$ values show statistically significance $(p<0.05)$

\section{DISCUSSION}

As uveal tissues and the conjunctiva have more blood circulation than other tissues in the eye, they are particularly sensitive to inflammatory reactions. In literature, it has been reported that the frequency of episcleritis, posterior scleritis and uveitis (anterior, intermediary and posterior) is increased in FMF patients. There are also studies that have reported retinal amyloidosis and conjunctival goblet cell destruction (5). However, there are few studies in literature related to the relationship between inflammation and the cornea. Kosekahya et al. mentioned that FMF patients have an increased risk of corneal ectasia compared to healthy subjects. Corneal tomographic features and the relationship of keratoconus with FMF may be important in a refractive surgery (6). The result is similar in our study, the CCT values were statistically significantly different between the FMF and control groups. The central corneal thickness value was found to be thinner in the FMF group. However, Kosekahya et al. made the tomographic analysis of all the eyes with Pentacam HR. Nevertheless, it is necessary to study more about this.

Mutations in the MEFV gene cause impairment in the immune response in tissue and the emergence of persistent inflammatory reactions. Interleukin (IL)-1 is a proinflammatory cytokine that provides the production of cytokines and chemokines and plays one of the most important roles in in- flammatory processes. Pyrin protein reduces the activation of IL-1B by inhibiting the catalytic activity of caspase-1. As pyrin interaction with caspase- 1 is reduced in the presence of the MEFV mutations in the B30.2 domain where pyrin protein binds to caspase-1, the mutations associated with FMF might be effective in reducing pyrin inhibition of IL-1B activation, and subsequently, IL-1B becomes more than usually active (9).

Keratocytes, which are present between collagen lamellae, maintain the structure of the corneal stroma. Metalloproteases that degrade extracellular collagen are produced by keratocytes. IL-1 and plasminogen are essential mediators for collagen degradation. The plasminogen system contributes to tissue repair through activation of the matrix metalloproteinases (MMPs), the release of growth factors from the extracellular matrix and degradation of the extracellular matrix. It is thought that urokinase-type plasminogen activator (uPA) is involved in corneal disorders and the regulation of wound healing in the cornea. In patients with corneal ulcerations, uPA is expressed in leukocytes and corneal fibroblasts suggesting that it may be a key regulator of corneal stromal degradation. UPA has direct involvement in plasmin-mediated collagen degradation which is induced by IL-1 and through the activation of MMP-9, has essential involvement in the promotion of leukocyte infiltration in corneal inflammation (10).

IL-1 has been shown to be associated with keratoconus and cause an increase in keratocytes apoptosis and collagen degradation (11). This could be a reason for the finding of thinner corneal thickness in the FMF group in the current study, and the result obtained is supported by this previous study.

Inflammation is known to reduce the expression of the aqueous humor by affecting the ciliary part and uveoscleral outflow (12). A reduction in aqueous humor causes impaired cornea metabolism and metabolic waste products and harmful components cannot be removed from the environment. To be able to overcome this unwanted situation, the cornea requires more oxygen and these triggers structural changes in the cornea resulting in a vicious circle of oxidative stress and inflammation. In the acute phase, the response of the cornea to this condition is swelling of the endothelial cells, stromal edema, increased corneal thickness. In corneas with chronic inflammation and tissue hypoxia, with the resorption over time of stromal edema, there is a deterioration of the stromal structure and there may be thinning with possible collagen loss. C. Mesut et al. showed that the effects of hypoxia on the cornea affected the cornea structurally (13). The results of the current study supported the view that the corneal structure was changed by inflammation and hypoxia together. 
The corneal metabolism depends on the conjunctival vascular network circulation, atmospheric oxygen and aqueous humor. In previous studies related to hypoxia, it has been shown that there are changes in the extracellular matrix through activation of collagenolysis of free radicals caused by structural changes in the stroma from the increased production of free radicals as a result of a series of reactions in corneas which chronically cannot provide sufficient oxygen $(14,15)$. Some studies have shown that hypoxia makes a negative contribution to prognosis in chronic inflammation and metabolic acidosis $(16,17)$.

Colchicine has a known adverse effect on wound healing through collagenase activation (18). Long-term use of colchicine for treatment in FMF patients may also be associated with collagenase activity and tissue destruction. Therefore, inflammation, hypoxia, and the use of colchicine are a series of complex mechanisms on cornea metabolism. There is a need for wider and more advanced studies to reach a clear knowledge of which factor is more effective on cornea tissue destruction. Our patients with FMF had used colchicine for an average of 3.1(2-8) years. According to this information, the use of colchicine longer may cause thinner cornea.

In our study, the mean ECD, CV, and percentage of hexagonality (HEXA)values were not statistically significant between groups. In a study in patients with uveitis, central ECD and percentage hexagonality was lower in eyes with uveitis (19). However, the anatomical localization of the uveitis in their study, the intensity and frequency of the uveitis attack may change the effect on the endothelium. Therefore, more and wider studies are needed on inflammation and corneal changes.

According to the results of our study, the thinner cornea in a patient with FMF may suggest that these patients are at risk for corneal ectasia in the future.

It's important to know that the patient is FMF, especially in refractive surgery, because with the effect of chronic inflammation, the final refraction may change over time. This information may change the surgical plans.

\section{CONCLUSION}

According to our hypothesis, more careful approach should be taken to FMF patients in corneal interventions because of the potential risk of corneal ectasia.

\section{ACKNOWLEDGEMENT}

Peer-Review

Externally Peer Reviewed

Conflict of Interest

The authors declare that they have no conflict of interests regarding content of this article..
Financial Support

No financial support was used by authors during this study.

\section{Ethical Declaration}

Ethical approval was obtained from the Hatay Mustafa Kemal University, Medical Faculty Clinical / Human Research Ethics Committee with number 2017/172 for this study, and Helsinki Declaration rules were followed to conduct this study.

\section{REFERENCES}

1. Sohar E, Gafni J, Pras M, Heller H. Familial Mediterranean fever: a survey of 470 cases and review of the literature. Am J Med 1967; 43:227-253. https://doi.org/10.1016/00029343(67)90167-2

2. The International FMF Consortium: Ancient missense mutations in a new member of the RoRet gene family are likely to cause FMF. Cell 1997; 90: 797-807. https://doi. org/10.1016/s0092-8674(00)80539-5

3. Mankan AK, Kubarenko A, Hornung V. Immunology in clinic review series; focus on autoinflammatory diseases: inflammasomes: mechanisms of activation. Clin Exp Immunol. 2012;167:369-381. https://doi.org/10.1111/j.13652249.2011.04534.x

4. Seshadri S, Duncan MD, Hart JM, Gavrilin MA, Wewers MD. Pyrin levels in human monocytes and monocyte-derived macrophages regulate IL-1beta processing and release. J Immunol.2007; 179:1274-1281. https://doi.org/10.4049/ jimmunol.179.2.1274

5. Petrushkin H, Stanford M, Fortune F, Jawad AS. Clinical Review: Familial Mediterranean Fever-An Overview of Pathogenesis, Symptoms, Ocular Manifestations, and Treatment. Ocul Immunol Inflamm. 2016 Aug;24(4):422-30. https://doi.org/1 $0.3109 / 09273948.2015 .1010012$

6. Kosekahya P, Ucgul Atilgan C, Atilgan KG, Koc M, Tekin $\mathrm{K}$, Caglayan M, et al. Increased Corneal Ectasia Risk in Patients with Familial Mediterranean Fever. Curr Eye Res. 2019;44(4):351-355. https://doi.org/10.1080/02713683.2018. 1554150

7. McCarey BE, Edelhauser HF, Lynn MJ. Review of corneal endothelial specular microscopy for FDA clinical trials of refractive procedures, surgical devices, and new intraocular drugs and solutions. Cornea 2008;27:1-16 https://doi. org/10.1097/ICO.0b013e31815892da

8. Doughty MJ, Müller A, Zaman ML. Assessment of the reliability of human corneal endothelial cell-density estimates using a noncontact specular microscope. Cornea 2000;19:148-158. https://doi.org/10.1097/00003226-200003000-00006

9. Chae JJ, Wood G, Masters SL, Richard K, Park G, Smith BJ, et al. The B30.2 domain of pyrin, the familial Mediterranean fever protein, interacts directly with caspase- 1 to modulate IL-1b production. Proc Natl Acad Sci U S A. 2006;103: 9982-9987. https://doi.org/10.1073/pnas.0602081103 
10. Sugioka K, Mishima H, Kodama A, Itahashi M, Fukuda M, Shimomura Y. Regulatory Mechanism of Collagen Degradation by Keratocytes and Corneal Inflammation: The Role of Urokinase-Type Plasminogen Activator. Cornea. 2016 Nov;35 Suppl 1:S59-S64. https://doi.org/10.1097/ ICO.0000000000000995

11. Kosker M, Arslan N, Alp MY, Itahashi M, Fukuda M, Shimomura Y. Association Between Keratoconus and Familial Mediterranean Fever in Turkey. Cornea. 2016 Jan;35(1):77-80. https://doi.org/10.1097/ICO.0000000000000662

12. Toris C B, Pederson J E.Aqueous humor dynamics in experimental iridocyclitis. Investigative Ophthalmology \& Visual Science March 1987, Vol.28, 477-481.

13. Coşkun M, Illhan Ö, Illhan N, Tuzcu EA, Daglıoglu MC, Kahraman $\mathrm{H}$., et al. Changes in the cornea related to sickle cell disease: a pilot investigation. Eur J Ophthalmol. 2015 NovDec;25(6):463-7. https://doi.org/10.5301/ejo.5000598

14. Wilhelm J, Herget J. Hypoxia induces free radical damage to rat erythrocytes and spleen: analysis of the fluorescent end-products of lipid peroxidation. Int J Biochem Cell Biol 1999;31:671-681. https://doi.org/10.1016/s13572725(99)00018-7
15. Mahelková G, Korynta J, Moravová A, J. Novotná, R. Vytášek, J. Wilhelm. Changes of extracellular matrix of rat cornea after exposure to hypoxia. Physiol Res 2008;57:73-80. https://doi. org/10.33549/physiolres.931087

16. Maurel S, Stankovic Stojanovic K, Avellino V, Girshovich A, Letavernier E, Grateau G et al. Prevalence and correlates of metabolic acidosis among patients with homozygous sickle cell disease. Clin J Am Soc Nephrol 2014;9:648-653. https:// doi.org/10.2215/CJN.09790913

17. Iampietro M, Giovannetti T, Tarazi R.,Girshovich A, Letavernier E, Grateau G, et al. Hypoxia and inflammation in children with sickle cell disease: implications for hippocampal functioning and episodic memory. Neuropsychol Rev 2014;24:252-265. https://doi.org/10.1007/s11065-014-9259-4

18. Alster Y, Varssano D, Loewenstein A, Lazar M. Delay of corneal wound healing in patients treated with colchicine. Ophthalmology. 1997 Jan;104(1):118-9. https://doi. org/10.1016/s0161-6420(97)30352-2

19. Alfawaz AM, Holland GN, Yu F, Margolis MS, Giaconi JA, Aldave AJ. Corneal Endothelium in Patients with Anterior Uveitis. Ophthalmology. 2016 Aug;123(8):1637-1645. https://doi. org/10.1016/j.ophtha.2016.04.036. 